\title{
Eril Kadın, Dişil Erkek ve Gezi Ruhu
}

\author{
Yasemin Sağlam ${ }^{1}$ \\ Fatma Ebru Özen²
}

\begin{abstract}
$\ddot{O} z$
Ataerkil bir cinsiyet düzenin hakim olduğu ülkemizde, toplumsal cinsiyet algist adaletsizce ve tek bir cinsiyet lehine yaşanmaktadır. Kadın her alanda eril bakış açısına göre şekillendirilmeye çalışılmaktadır. Erkek ve kadın arasındaki temel fark biyolojik olmasına rağmen kadın, ataerkil toplumlarda tarihin hiçbir döneminde erkekten daha önde olamamıştır. Gezi Parkı olayları Türk kadını açısından önemlidir. Eril sistemin yarattı̆̆ yapıya ilk başkaldırısı olmasa da görünürlüğ̈̈ açısından en etkili başkaldırısıdır. Kadınlar ilk defa bir eylemde bu derece görünür olmuşlar, erkeklerle birlikte, omuz omuza, demokratik haklarını savunmak için, şiddete karşı durmak için, gelecekleri için direnmişlerdir. Bu çalışmada, kadını erkekle sokakta eşitleyen ve görünür kılan Gezi olaylarının karakteristik özelliklerine bakılarak eylemin eril mi dişil mi olduğu sorgulanmaktadır.
\end{abstract}

Anahtar Sözcükler: Gezi Parkı olaylarl, Toplumsal cinsiyet, Eril, Dişil, Kadın.

\section{Masculine Women, Feminine Men and Gezi Soul}

\begin{abstract}
In our mainly patriarchal country, social gender perception is unfair to women and to the advantage of male sex. Women are shaped in all areas according to the male point of view. Even though the only difference is in their physical and biological nature, in partriarchal societies, women could never be ahead of men in the history of mankind. Gezi Park events were a turning point for women. For the first time, women were this visible, alongside and shoulder to shoulder with men; they stood against violence, defended their democratic rights and their future; they became equals with men in public arena. In this study, by observing the characteristics and particulars of Gezi Park events which liberated women, made them visible and equals to men, we examine these events in terms of being male or female in nature.
\end{abstract}

Keywords: Gezi Park events, Social gender, Male, Female, Woman

1 AÜ Yaratıcı Drama Yüksek Lisans Programı Öğrencisi E-Posta:yasemingunduz75@hotmail.com

2 MEB Gülveren Anadolu Lisesi (Blm.Uzm) E-Posta: ebrukaan@gmail.com 


\section{Giriş}

Ataerkil bir cinsiyet düzenin hakim olduğu ülkemizde, toplumsal cinsiyet algısı adaletsizce ve tek bir cinsiyet lehine yaşanmaktadır. Kadının, evde, işte ve sosyal yaşam içinde varoluşu eril baskı altında olmaktadır. Eril bakış açısı hem özel hem de kamusal alanda kadını şekillendirmeye çalışmaktadır. Bu nedenledir ki kadın, varoluşuyla birlikte dünyada ve de Türkiye'de bir 'var olma' mücadelesinin içinde bırakılmış; toplumsal cinsiyet kalıpları üzerinden kendisine yönelen fiziksel, duygusal, sözel şiddete karşı direnmek zorunda kalmıştır.

Sosyal, siyasal ve insani haklarına kavuşmak için devlete, erkeğin iktidarına, her türlü şiddete karşı direnmek kadının yaşamının en temel parçası haline gelmiştir. Kadının özel alanda yalnız, kamusal alanda örgütlü direnişi 2013 Haziran'ına kadar toplumun çok az bir kesimi tarafindan görülmüştür. Kadının direnişi 2013 Haziran'ında, Gezi Parkı eylemlerinde, Türkiye Cumhuriyeti’nin kuruluşundan bugüne kadar olan tüm direniş öyküsünden bambaşka bir boyutta ortaya çıkmıştır. Peki bu eylemde kadını ve sorunlarını bu kadar görünür kılan neydi?

Gezi Direnişi’nde, kadının örgütlü-örgütsüz, sokakta, erkeklerle birlikte omuz omuza ve fazla görünür olması, araştırmacıları "Peki herkesi ve de özellikle kadınları sokağa taşıyan bu eylemin özelliği neydi?", "Eyleme acaba ne kadar kadın katıldı?", "Kadınlar çok olduğu için mi farklı bir eylemdi?" sorularıyla karşı karşıya bırakmış, yapılan ön çalışma sonrasında da çalışmanın amacını oluşturan soruya ulaşılmıştır: "Gezi Eylemi dişil miydi?"

$\mathrm{Bu}$ çalışmanın amacı, kadını erkekle sokakta eşitleyen ve görünür kılan Gezi olaylarının karakteristik özelliklerine bakılarak eylemin eril mi dişil mi olduğunu sorgulamaktır. Bu soruyu cevaplandırabilmek için öncelikle, cinsiyet kavramından başlayarak erkek ve kadın kavramlarının kısaca tanımlanması; ardından da toplumsal cinsiyet bağlamında erillik ve dişillik kavramlarının açıklanması gerekmektedir.

\section{Literatür Taraması}

İnsan biyolojik olarak ele alındığında iki cinsiyet vardır: kadın ve erkek. Temel olarak üreme sistemleri bu iki cinsi birbirinden ayırmaktadır; ancak genetik yapıdaki bu fark, bu iki türün sadece cinsel organlarında değil, vücut 1sılarından, kas iskelet sistemlerindeki yapıya; ses tellerinin uzunluk ve kısalıklarından, duyu organlarının güç seviyelerine; beyin ağırlıklarından, bedenlerinde taşıdıkları kanın miktarına kadar çok sayıda fiziksel farklılıkları da beraberinde getirmektedir. Tüm bu söz edilen farklarla birlikte ama bunların da ötesinde, kadın ve erkeğin toplum içinde değerlendirilen cinsiyet özellikleri bulunmakta, bu da toplumsal cinsiyet olarak adlandırılmaktadır.

Erillik ve dişillik kavramlarından bahsedebilmek için öncelikle; erkeklik, kadınlık ve toplumsal cinsiyet kavramlarına açıklık getirmek gerekmektedir. Türk Dil Kurumu Sözlüğü’ne göre cinsiyet "bireye üreme işinde ayrı bir rol veren ve erkekle dişiyi ayırt ettiren yaradılış özelliği, eşey, cinslik, seks" olarak tanımlanmaktadır. Tanımdan da anlaşılacağı üzere cinsiyet kavramı, kadın ve erkeği biyolojik olarak ele almaktadır. Bu biyolojik sınıflama erkek, kadın kelimelerinin anlamlarına bakıldığında da net olarak görülmektedir. Erkek: 1-Yetişkin adam, bay, er kişi. 2- İnsan, hayvan ve bitkilerin dişiyi dölleyecek cinsten olanı (TDK Sözlük, 2004). 3- Sperma oluşturan organizma. Kadın: 1-Erişkin dişi insan, hatun, hatun kişi, zen. 2- Analık veya ev yönetimi bakımından gereken erdemleri, becerileri olan (TDK Sözlük, 2004). 
Erkek ve kadın, cinsiyetin biyolojik anlamını ifade ediyorsa, eril ve dişil kavramlarıyla tanımlanan nedir? Eril ve dişil, kadın ve erkeğin toplumsal cinsiyet kavramı içinde sosyal olarak sınıflandırılmasıyla ortaya çıkmaktadır. Erillik ve dişillik hem sosyal hem de kültürel kavramlardır ve her toplum kendi kültürüne göre kavramsallaştırır. Erillik ve dişillik sosyal ve kültürel birer kavramdır, dolayısıyla toplumların kendi kültürel yapılarına göre farklılık gösterir. Yani her toplum erkeklik ve kadınlık değerlerini kendisi yaratır.

Biyolojik cinsiyet doğuştan kazanılır, toplumsal cinsiyet ise öğrenilir ve dolayısıyla sosyaldir. Her toplum bazı faaliyetlerin erkeğe, diğerlerinin ise kadına ait olduğuna ilişkin düşünceye sahiptir (Henslin, 2003, s.289'dan akt.: Sankır, 2010). Toplum, kadın ve erkekle özdeşleştirilen kavramları, zamanla kadınsı ve erkeksi olarak kodlamakta; kadından ve erkekten kodladığı şekilde davranmasını beklemektedir. Yani erillik ve dişillik, erkeğin ve kadının biyolojik özelliklerinin ötesinde, erkek ve kadın olmalarından dolayı, nasıl düşündükleri, neler hissettikleri ya da nasıl davrandıklarına ilişkin kabullenmeleridir.

Kadın ve erkeğin toplumsal hayata katılım biçimi, katılım oranı, toplum içindeki varlığ 1 ve yine toplum tarafindan algılanışı, toplumda geçerli olan toplumsal cinsiyet algısından etkilenmekte; toplumsal cinsiyet algısı ise o toplumun sosyal ve kültürel yapısından etkilenmektedir. Modern çağla birlikte kadın ve erkeğe yüklenen bu toplumsal roller zaman içinde değişim göstermiştir. Çağımızda erkek sadece eril, kadın ise sadece dişil tavır sergilememekte, gerek özel alan gerekse toplumsal alanda erkekler dişil, kadınlar ise eril tavırlar sergilemektedirler.

Toplumsal cinsiyet rolünün erkek ve kadın için uygun etkinlik ve niteliklerinin kesin olarak saptanabildiğini belirtilmektedir (Oglesby ve Hill, 1993, s.720'den akt.:Sankır, 2010). Hırsl1, rekabetçi, otoriter vb. roller eril olarak nitelenirken; sevecen, merhametli, yardıma muhtaç vb. roller ise dişil olarak nitelenmektedir. Yapılan çalışmalar sonucu Türkiye'de ve dünyada tespit edilmiş eril ve dişil olarak tanımlanmış çok sayıda rol vardır. Bu rollerden, eril ve dişillik sorgulaması yapmak için bilimsel çalışmalarda kullanılmak üzere seçilmiş olanları bu çalışmanın ölçek kısmında kullanılmıştır.

\section{Yöntem}

\section{Araştırmanın Amacı}

Bu çalışmanın amac1; örgütlü, örgütsüz, Müslüman, Ateist, Alevi, Türk, Kürt, sağc1, solcu tüm halkı sokağa taşıyan ve ortak bir paydada buluşturan; Türkiye tarihindeki ilk halk ayaklanması niteliğindeki bu eylemin dişil mi yoksa eril mi olduğunun saptanmasıdır.

\section{Verilerin Toplanması ve Analizi}

Çalışmanın ölçek kısmı, araştırmacılar tarafından üç bölüm halinde hazırlanmıştır. Ölçeğin birinci bölümünde, katılımcı profilini tanımlayan sorular vardır. İkinci bölümünde, Gezi Eylemleri’ne katılanların davranışlarını irdeleyen sorular yer almıştır. Üçüncü bölümde Hükümetin Gezi Eylemleri sırasında medya aracılığıyla doğrudan ve polis aracılığıyla dolaylı olarak sergilediği tavrı değerlendirmek için hazırlanmış sorular bulunmaktadır. Ölçek hazırlanırken, Doç. Dr. Zehra Yaşın Dökmen'in “Bem Cinsiyet Rolü Envanterinin geçerlik ve güvenirlik çalışması”nda belirtilen 20 eril 20 dişil 40 sıfattan 25 tanesi ve kaynakçadaki makalelerden de 15 sıfat seçilmiş ve bu sıfatlar ölçekte 
kullanılmıştır. Geliştirilen ölçekte iki adet çalışmayan madde tespit edilmiş, bu sorular 2. bölümün 21. sorusu ve 3. bölümün 22. sorusu olarak tespit edilmiştir. 238 anket kağıdından 62 tanesinde (\%26) eril bir sıfat olan "cömert" ve 48 tanesinde (\%20) yine eril bir sıfat olan "gözüpek" sıfatlarına verdikleri "kararsızım" seçeneği ile araştırmacılara bu maddenin çalışmasını sorgulatmışlardır. Bununla ilgili ayrıntı öneriler kısmında verilmiştir. Anketin uygulanmasında, Gezi Eylemi’ne katılma veya destekleme koşulu aranmamıştır.

Araştırmada elde edilen verilerin analizi için, nicel analiz yöntemi kullanılmıştır. Nicel analiz verileri, beşli likert tipinde ölçek aracılığıyla toplanmıştır. Hazırlanan ölçek bir bilim uzmanı ve bir dilbilimci tarafından kontrol edilmiştir. Değerlendirme, SPSS 16.0 programı kullanılarak araştırmacılar tarafından yapılmıştır.

\section{Evren ve Örneklem}

Araştırmanın evrenini Türkiye'nin yedi bölgesini temsil ettiğini düşündügümüz iller oluşturmaktadır. Bu araştırma, araştırmacıların Türkiye'nin seksen bir iline ulaşma güçlüğü, zaman sıkıntısı ve getireceği mali külfetler nedeni ile Türkiye'nin otuz iki ilinden ulaş1lan katılımcılarla gerçekleştirilmiştir. Araştırmada kullanılan illerin bölgelere göre dağılımı şu şekildedir: Marmara bölgesinden Bursa, Çanakkale, İstanbul, Kocaeli, Tekirdağ, Sakarya; Ege bölgesinden Aydın, Denizli, İzmir, Muğla; Akdeniz bölgesinden Antalya, Hatay, Mersin; İç Anadolu bölgesinden Ankara, Artvin, Eskişehir, Kayseri, Konya, Yozgat; Karadeniz bölgesinden Bartın, Bolu, Kastamonu, Rize, Samsun, Trabzon Zonguldak; Doğu Anadolu bölgesinden Elazığ, Erzurum, Van; Güneydoğu Anadolu bölgesinden Diyarbakır, Kahramanmaraş, Şanlıurfa şeklindedir. Bu iller ve anket uygulanan 238 kişi araştırmanın örneklemini oluşturmuştur.

Araştırmada ulaşılan bölgelerdeki veri toplama aracının uygulandığı kişiler kartopu örnekleme yolu ile seçilmiştir. Kartopu örnekleme yolu bir evrenin ögeleri basit tesadüfi örneklem ya da tarama yoluyla kolayca tespit edilemeyen veya seçilecek ögelerin evrendeki diğer ögeleri bildikleri durumlarda kullanılmaktadır. Bu grupların belli bir sayıda araştırmada yer almaları doğrudan amaçlanmamıştır ancak ulaşılanlardan hareketle diğer hedef gruplara ulaşılması (kartopu yöntemi) sağlanmıştır.

\section{Bulgular}

Araştırma kapsamında toplam 238 kişiye uygulanan anket sonucunda ulaşılan bulgular; Ankete katılan katılımcı profiline ilişkin bulgular, Eylemcilerin Davranışlarının Değerlendirilmesine İlişkin Bulgular başlıkları altında ele alınmıştır.

\section{Ankete Katılan katılımeı Profiline İlişkin Bulgular}

Ankete katılanların \%40’1 erkek, \%60'1 kadındır. Ankete katılanların yaş aralığına göre dağılımı şöyledir: \%21'i 15-24 yaş grubunda, \%35'i 25-34 yaş grubunda, \%32'si 35-44 yaş grubunda, \%8'i 45-54 yaş grubunda ve \%4'ü 55 yaş ve üzeridir. Ankete katılanların \%48'i evli, \%52'si bekardır. Ankete katılanların meslekleri; arkeolog, avukat, bankacı, çevirmen, danışman, eczacı, editör, esnaf, gazeteci, grafik tasarımcısı, halkla ilişkiler uzmanı, hekim, hemşire, kuaför, memur, mimar, muhasebeci, mühendis, müzisyen, öğretim üyesi, öğretmen, pazarlamac1, radyoloji teknisyeni, sağlık teknikeri, sekreter, serbest meslek, tiyatrocu, sosyal hizmet uzmanı, tasarımcı, terzi, 
turizmci, yönetici şeklindedir. Bu mesleklerin dışında, emekli, ev hanımı, işsiz ve öğrenci grupları da anketin katılımcıları arasındadır.

Ankete katılanların yaşadıkları illerin bölgelere göre dağılımı şöyledir: \%35'i İç Anadolu Bölgesi’nden, \%13’ü Marmara Bölgesi’nden, \%11'i Ege Bölgesi'nden, \%12si Akdeniz Bölgesi'nden,\%15'i Karadeniz Bölgesi'nden, \%11'i Doğu Anadolu Bölgesi’nden, \%3'ü Güneydoğu Anadolu Bölgesi'ndendir.

Ankete katılanların \%2,5'i ilkokul ve ortaokul , \%9'u lise, \%12'si önlisans, \%58'i lisans, \%18,5'i lisansüstü ve doktora düzeyinde öğrenim görmektedir veya öğrenimini tamamlamıştır. Ankete katılanların \%58'i gezi eylemlerine katılmamış, \%42'si katılmıştır.

\section{Eylemcilerin Davranışlarının Değerlendirilmesine İlişkin Bulgular}

Anketin ikinci bölümünde, eylemcilerin davranışlarının değerlendirilmesi ile ilgili dişil ve eril sıfatların kullanıldığı sorularla ilgili bölümün sonuçları Tablo 1 ve Tablo 2' de verilmiştir.

Tablo 1. Eylemcilerin Davranışlarının Dişil Sıfatlar Açısından Değerlendirilmesi

\begin{tabular}{|c|c|c|c|c|c|c|c|}
\hline \multirow[b]{2}{*}{ DİŞiL SIFATLAR } & \multicolumn{5}{|c|}{ KATILMA DÜZEYİ(\%) } & \multirow{2}{*}{\multicolumn{2}{|c|}{ 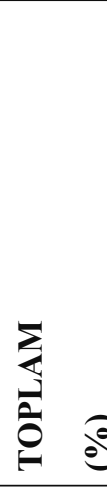 }} \\
\hline & 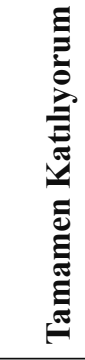 & 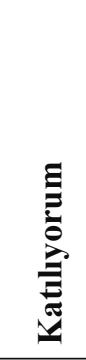 & 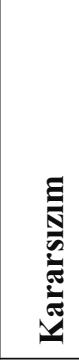 & 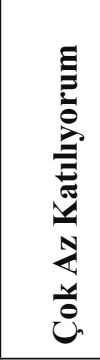 & 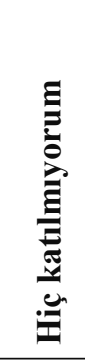 & & $e^{\ominus}$ \\
\hline İnsani değerlere karşı duyarlı & 55 & 28 & 2 & 6 & 9 & 100 & \\
\hline Fedakar & 31 & 38 & 7 & 10 & 14 & 100 & \\
\hline Hassas & 39 & 40 & 2 & 8 & 11 & 100 & \\
\hline Duygusal & 32 & 33 & 13 & 11 & 11 & 100 & \\
\hline Sevecen & 33 & 37 & 9 & 10 & 11 & 100 & \\
\hline Sorumlu & 45 & 34 & 4 & 7 & 10 & 100 & \\
\hline Merhametli & 25 & 33 & 11 & 12 & 19 & 100 & \\
\hline Uzlaşmacı & 23 & 35 & 9 & 11 & 22 & 100 & \\
\hline Sadık & 55 & 27 & 5 & 6 & 7 & 100 & \\
\hline Merhamet & 24 & 29 & 9 & 13 & 25 & 100 & \\
\hline Yardıma muhtaç & 10 & 20 & 15 & 17 & 38 & 100 & \\
\hline ORTALAMA & 34 & 32 & 8 & 10 & 16 & 100 & \\
\hline
\end{tabular}

Ankete katılanların \%66'sı Gezi Eylemi’ndeki eylemcilerin davranışlarını dişil sıfatlarla tanımlamışlardır. Dişil sıfatların en fazla görüldüğü yüzdeler: \% 83 ile "insani değerlere duyarlı", $\% 83$ ile sadık, \% 79 ile sorumlu, \% 79 ile hassas, \% 70 ile sevecen ve $\% 68$ ile fedakar olarak tespit edilmiştir. 
Tablo 2. Eylemcilerin Davranışlarının Eril Sıfatlar Açısından Değerlendirilmesi

\begin{tabular}{|c|c|c|c|c|c|c|}
\hline \multirow[b]{2}{*}{ ERİL SIFATLAR } & \multicolumn{5}{|c|}{ KATILMA DÜZEYİ(\%) } & \multirow[b]{2}{*}{ 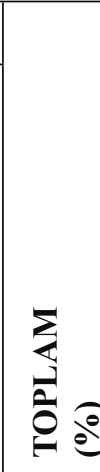 } \\
\hline & 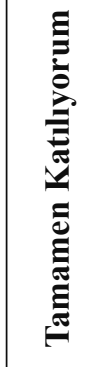 & 莞 & 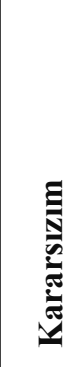 & 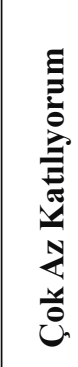 & 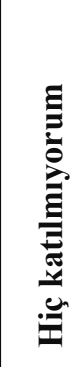 & \\
\hline Etkileyici, güçlü & 27 & 28 & 9 & 13 & 23 & 100 \\
\hline Haksızlığa karşı tavır alan & 61 & 23 & 4 & 2 & 10 & 100 \\
\hline İdealist & 44 & 30 & 6 & 10 & 10 & 100 \\
\hline Kendi ihtiyaçlarını savunan & 42 & 29 & 7 & 9 & 13 & 100 \\
\hline Kendine güvenen & 35 & 40 & 8 & 9 & 8 & 100 \\
\hline Mantıklı & 33 & 39 & 10 & 8 & 10 & 100 \\
\hline Riski göze almaktan çekinmeyen & 38 & 37 & 6 & 9 & 10 & 100 \\
\hline Çatışmacı & 11 & 12 & 12 & 17 & 48 & 100 \\
\hline Haksızlığa karşı duran & 35 & 36 & 8 & 10 & 11 & 100 \\
\hline Cömert & 17 & 22 & 26 & 13 & 22 & 100 \\
\hline Kuralcı ve katı & 4 & 9 & 13 & 14 & 60 & 100 \\
\hline ORTALAMA & 32 & 28 & 10 & 10 & 20 & 100 \\
\hline
\end{tabular}

Ankete katılanların \%60’1 Gezi Eylemi’ndeki eylemcilerin davranışlarını eril sıfatlarla tanımlamışlardır. Burada eril sıfatların en fazla görüldüğü yüzdeler ise: \%84 ile haksızlığa karşı tavır alan, $\% 75$ ile kendine güvenen, $\% 75$ ile riski göze almaktan çekinmeyen, $\% 75$ ile idealist, $\% 72$ ile mantıkl1, \%71 ile kendi ihtiyaçlarını savunan ve \%71 ile haksızlığa karşı duran olarak belirlenmiştir.

Gezi Eylem'inin yapısına bakıldığında daha ilk adımda eylemin türünün “pasif direniş” olarak belirlenmesi dikkat çekmektedir. Pasiflik, dişil bir kavramdır ve pasif direniş şiddet içermez; şiddet, eril roller içinde sıralanan bir kavramdır. Diğer taraftan, pasif direniş aynı zamanda yasal olmayan politik bir eylemdir; oysa siyaset, geçmişten beri daima saldırganlık ve erkeksilikle (maskülenlikle) değerlendirilen yani eril bir kavramdır. Buradan hareketle sadece "pasif" ve "direniş" kelimelerinin bile bir araya gelmesi ortaya çıkan yapının farklılığını işaret etmektedir.

CHP Genel Başkan Yardımcısı ve Sosyolog Prof. Dr. Sencer Ayata, Prof. Dr. Emre Kongar’a yaptığ 1 değerlendirmelerde, Gezi eylemcilerinden 1990 doğumlu gençlerin isyanının altında, "yaşam tarzıma dokunma, değerlerimi aşağılama” tavrının yattığı görüşündedir (Kongar, 2013, s.36). Dişil kültürün endişe ve yaşam kalitesine sahip olma durumu olarak nitelendirdiği göz önüne alındığında, eylemcilerin yine dişil kültür bağlamında "yaşamın genel niteliğini önde tutma" tavrı içinde oldukları ve bu tavırla da dişil yanlarını sergiledikleri söylenebilir. 
Ayata'nın bu saptamalarının yanı sıra bu çalışmada yaşamın genel niteliğini koruma ve ona sahip çıkma eğilimi içinde sergiledikleri \%75 ile kendine güvenen, \%75 ile riski göze almaktan çekinmeyen, $\% 75$ ile idealist, $\% 72$ ile mantıkl1, \%71 ile kendi ihtiyaçlarını savunan ve $\% 71$ ile haksızlığa karşı duran tavırları ise eylemin eril yanını göstermektedir.

KONDA Araştırma ve danışmanlık şirketinin yaptığı araştırmaya göre eyleme katılanların \% 50,9'unun kadın olduğu tespit edilmiştir (Kongar, 2013, s.32). Gezi Eylemleri'nin dikkat çeken bir başka özelliği ise kadının bu eylemlerdeki görünürlügüdür. Cumhuriyet'in kuruluşundan bu yana Türkiye Cumhuriyeti tarihinde gerçekleşmiş eylemlerin içinde "kadın" her zaman olmuş; ancak hiçbir eylemde bu kadar görünür olmamıştır. Alan uzmanları buna neden olarak kadının siyasetle olan ilişkisindeki mesafeyi gerekçe olarak göstermektedirler. Taylor'a göre, erkeklerin tarih ağırlıklı olarak dışarı ve iş yaşamıyla yani "kamusal alan”la özdeşleştirilirken, kadınların “özel alan”la özdeşleştirilmesinin, kadının görünürlüğünü azaltan en önemli etkenlerden biri olarak belirtmektedirler (Taylor ve diğerleri, 2007, s.362'den akt.: Sankır, 2010).

Yine kadının özel alanla özdeşleştirilmesi, toplumsal rolünü edilgen hale getirmiştir. Buradan hareketle kadının yeri kamusal alanda erkeklerinkinden aşağıda tanımlanmıştır. Bu nedenledir ki eril kültür, kadını "başarılı erkeğin arkasındaki” kişi olarak görmektedir. Yani kadın, lider değildir yardımcıdır. Gezi Eylemleri’nde ise kadın erkeğin arkasında değil yanında, onunla aynı şartlar altında bulunmuş, kamusal alanda eşit koşullar altında aynı mücadeleyi verebildiğini göstermiştir. Buradan hareketle, Gezi Eylemleri’nde “sokak, kadınla erkeği eşitlemiştir” denilebilir.

Peki neden Gezi Eylemleri’nde kadın görünür olmaktan da öte Gezi Eylemleri’nin sembolü haline gelmiştir? Carnaghan/Bahry,Pratto/Stallworth'a göre 1950'li ve 1960'lı yılların siyasal bilim literatürünün çoğunda kadınlar edilgen, duygusal, desteğe muhtaç, siyasete ilişkin konularda bilgisiz, siyasal çatışmalardan rahatsız, siyasete ilgisiz bir tablo çizmektedirler (Carnaghan/Bahry, 1990, Pratto/Stallworth, 1997'den akt.: Güldü ve Kart, 2009). Bununla birlikte son 50 yıllık süreç içinde, kadın ve erkeğe yüklenen toplumsal roller içinde, siyasal tutumları geçmişe göre değişim göstermiş̧tir. Kadının eril sistemde kendine uygun görülen özel alan (ev) dışına çıkması ve çalışma yaşamına girmesi, siyasal tutumunun değişmesine neden olarak gösterilmektedir. Araştırmalar ev dışında çalışan kadınların, cinsiyet rolleri ve eşitlik konularında çok daha liberal ve feminist eğilimler taşıdıklarını ortaya koymaktadır (Güldü ve Kart, 2009).

Yukarıdaki açıklamalardan yola çıkarak, kadınların gerek nicelik olarak gerekse nitelik olarak bu kadar etkin katılmasına sebep olarak; kadının dişil tavrının yıllar içinde eril özellikler kazanarak hem eril hem de dişil bir yapıya dönüşmesi gösterilebilir. Kadın, erkekle sokakta her türlü şiddete karşı omuz omuza direnmiş, eril kültürün erkek işi saydığı bir çok iş ve zorluğa birlikte göğüs germiştir. Kadınların, TOMA'ların önünde, barikatların kurulumunda, biber gazı altında, parkta kurulan yaşam içinde dişilliğinden ödün vermeden ama kararl1, gözüpek, kendine güvenen, idealist gibi eril sıfatlarla nitelenen eril duruşu, medyanın ve toplumun dikkatini çekerek kadını ve sorunlarını ilk defa bu derecede görünür kılmıştır.

Lindsey'e göre yapılan çalışmalarda çağın hiçbir toplumunda erkeğinin statüsünün kadının gerisine düştüğü görülmemiştir (Lindsey L, 1990, s.3-5, akt.: Çatalcalı, 2002). Tarihsel açıdan değerlendirildiğinde bu saptamanın Türkiye açısından da geçerli olduğu sonucu çıkarılabilir; ta ki Gezi Eylemleri'ne kadar. Gezi Eylemleri’ne bakıldığında, Türk kadını eril kültür karşısında, yine eril tavırlar sergileyerek Türkiye tarihinde ilk defa bu kadar öne çıkmıştır. Bugüne kadar çoğunlukla 
örgütlü ve sol eğilimli kadınların verdikleri mücadeleyi, Gezi de örgütlü-örgütsüz, solcu-sağcı, türbanl1-açık tüm kadınlar hep birlikte ve erkeklerle omuz omuza vermişlerdir.

Kavakl1, "Direnişin Kadın Hali" adlı yazısında, kadınların bu anlamda Gezi Eylemi'nin önemli bileşenlerinden olduklarını, bunun sonucunda da eylem'in gidişatını, yapısını ve uygulanışını önemli ölçüde değiştirdiklerini öne sürmektedir (Sancar, 2013, s.293). Erdem Yörükoğlu ise "Direnişin Sosyal ve Siyasal Koşulları" adlı yazısında, kadınların hem özgürlüklerini hem de geleceklerini korumak için sokağa indiklerini belirterek, kadınların Gezi Eylemleri'nin en önde gelen aktörleri olduklarını ifade etmektedir (Sancar, 2013, s.19).

Dişil kültürün Gezi Eylemleri’ne etkisine yönelik en önemli ölçütlerinden birisinin de “Gezi’nin dili” olduğu söylenebilir. Tamamen küfürsüz olduğu söylenememekle birlikte, eylemin, dişil kültürün barışçıl ve samimi diline sahip olduğu da görülmektedir. Gezi eylemlerinin, gerek sözlü gerekse davranışsal açıdan diline bakıldığında etkileyici bir dile sahip olduğu göze çarpmaktadır. Eylemin katılımcı profilinin, oldukça eril davranışlara sahip olan taraftar gruplarından, salon beyefendilerine; ev hanımlarından, hayat kadınlarına; eşcinsellerden Anti-kapitalist Müslümanlar'a kadar oldukça kozmopolit bir yapısı olduğu göz önüne alındığında, eylem dilinin kimlikler üstü olduğu görülmektedir.

Eylemleri yakından izleyen Irmak Zileli, eylemin dili açısından önemli ipuçları sunan, eylemcilerin davranışları ile ilgili tespitlerini şöyle sıralıyor: Polis gaz sıkarken, aynı karede görüntülenen yerleri süpüren genç, panik içinde kaçışırken çarpışanların birbirlerine pardon diyenler, yaralı sedyesinin gelmekte olduğunu "Açılın martı" ifadesiyle dile getirenler(Kongar, 2013, s.42). $\mathrm{Bu}$ ve bunun gibi burada sıralanamayacak kadar çok örnek, eylemcilerin tutumları açısından eylemin dişil; anket sonuçlarına göre polis saldırıları sırasındaki tutumlarında ise \%84 ile haksızlığa karşı tavır alan, \%75 ile kendine güvenen, $\% 75$ ile riski göze almaktan çekinmeyen, $\% 75$ ile idealist; $\% 72$ ile mantıklı, \%71 ile kendi ihtiyaçlarını savunan, \%71 ile haksızlığa karşı duran olarak eril bir duruş sergiledikleri belirlenmiştir. Burada da yine eril ve dişil tavrın birlikte ortaya çıkmış olması dikkat çekmektedir.

Gezi Eylemleri’nin karakteri hakkında üzerinde durulması gereken bir diğer konu ise eylemde kullanılan sloganların dilidir. Gezi sloganları, Türk halkının alışkın olduğu ve yıllardır duymaya alıştığ 1 tarzda değildir. Erillik-dişillik bağlamında sloganların en göze çarpan özelliği; eylemcilerin kim oldukları, neden orada oldukları, ne istedikleri ve neler hissettiklerini çok net ifade etmesi ve bu yönüyle dişil olmasıdır. "Biz AKP'siz dine, CHP'siz Ataya, BDP'siz Kürde sahip çıkarız, biz halkız.”, "AVM değil, orman istiyoruz.", "sıkma demiyorum, hobi olarak gene s1k", "sinirlenince çok güzel oluyorsun Türkiye" vb. sloganlar aracılığıyla duygularını bu kadar net ve kaba bir dil kullanmadan anlatmış olması eylemin dişil yönünü ortaya çıkarırken; "TC'yi kaldırdın ama ayağa", "Gazın mı bitti abisi", "Gaza geldik", "Polis simit sat, onurlu yaşa" vb. sloganların erkeksi, kararlı, idealist ifadeler içeriyor olması ise eylemin dilinin eril tarafını açığa çıkarmaktadır.

\section{Hükümetin Medya ve Polis Aracılığıyla Sergilediği Tutumun Değerlendirilmesi}

Anketin üçüncü bölümünde hükümetin medya ve polis arac1lığıyla sergilediği tutumun değerlendirilmesi ile ilgili dişil ve eril sıfatların kullanıldığı sorularla ilgili bölümün sonuçları Tablo 3 ve Tablo 4'te verilmiştir. 
Tablo 3. Hükümetin Medya ve Polis Aracılığıyla Sergilediği Tutumun Dişil Slfatlar Açısından Değerlendirilmesi

\begin{tabular}{|c|c|c|c|c|c|c|c|}
\hline \multirow[b]{2}{*}{ DİŞIL SIFATLAR } & \multicolumn{5}{|c|}{ KATILMA DÜZEYİ(\%) } & \multirow{2}{*}{\multicolumn{2}{|c|}{$\sum_{0}^{\infty}$}} \\
\hline & 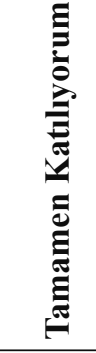 & 泀 & 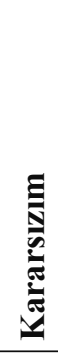 & 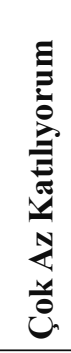 & 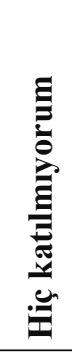 & & \\
\hline Fedakar & 2 & 5 & 5 & 10 & 78 & 100 & \\
\hline Merhametli & 2 & 4 & 5 & 11 & 78 & 100 & \\
\hline Pasif & 3 & 5 & 6 & 8 & 78 & 100 & \\
\hline Kaba dil kullanmayan & 4 & 5 & 6 & 9 & 76 & 100 & \\
\hline Duygusal & 6 & 8 & 5 & 10 & 71 & 100 & \\
\hline Anlayışlı & 3 & 4 & 4 & 12 & 77 & 100 & \\
\hline Uzlaşmacı & 3 & 6 & 4 & 13 & 74 & 100 & \\
\hline Kibar & 1 & 4 & 3 & 12 & 80 & 100 & \\
\hline Boyun eğen & 1 & 3 & 3 & 8 & 85 & 100 & \\
\hline Cana yakın & 1 & 3 & 4 & 11 & 81 & 100 & \\
\hline Ağırbaşlı ve ciddi & 5 & 15 & 9 & 13 & 58 & 100 & \\
\hline ORTALAMA & 3 & 6 & 5 & 10 & 76 & 100 & \\
\hline
\end{tabular}

Ankete katılanların \%86'sı gezi eyleminde hükümetin medya ve polis aracılığıyla sergilediği tutumu dişil bulmamışlardır.

Tablo 4. Hükümetin Medya ve Polis Aracılı̆̆ıyla Sergilediği Tutumu Eril Sıfatlar Açısından Değerlendirilmesi

\begin{tabular}{|c|c|c|c|c|c|c|}
\hline \multirow[b]{2}{*}{ ERİL SIFATLAR } & \multicolumn{5}{|c|}{ KATILMA DÜZEYİ(\%) } & \multirow[b]{2}{*}{ 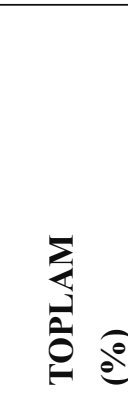 } \\
\hline & 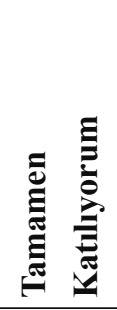 & E & 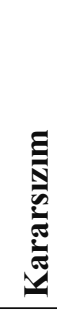 & 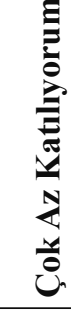 & 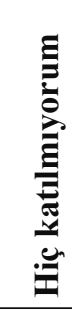 & \\
\hline Baskın ve tesirli & 24 & 32 & 6 & 11 & 27 & 100 \\
\hline Duygularını açı̆̆a vurmayan & 9 & 18 & 11 & 9 & 53 & 100 \\
\hline Etkileyici ve güçlü & 15 & 21 & 13 & 11 & 40 & 100 \\
\hline Otoriter & 47 & 27 & 8 & 5 & 13 & 100 \\
\hline Kuralc1 ve kat1 & 57 & 26 & 5 & 6 & 6 & 100 \\
\hline Etkin, aktif & 40 & 32 & 11 & 8 & 9 & 100 \\
\hline Hakimiyet kurmaya çalışan & 65 & 25 & 3 & 3 & 4 & 100 \\
\hline Çatışmacı & 63 & 22 & 4 & 3 & 8 & 100 \\
\hline Saldırgan & 66 & 17 & 3 & 5 & 9 & 100 \\
\hline Kendine güvenen & 30 & 29 & 14 & 9 & 18 & 100 \\
\hline Gözüpek & 24 & 28 & 20 & 12 & 16 & 100 \\
\hline ORTALAMA & 40 & 25 & 9 & 7 & 19 & 100 \\
\hline
\end{tabular}


Ankete katılanların \%65'i hükümetin medya ve polis aracılığıyla sergilediği tutumu eril sıfatlarla tanımlamışlardır. Bu eril sıfatların \%90'ı hakimiyet kurmaya çalışan, \%85'i çatışmacı, \%83'ü kuralc1 ve kat1, \%83'ü saldırgan, \%74'ü otoriter, \%72'si etkin, aktif olarak belirlenmiştir.

\section{Tartışma ve Sonuç}

Gezi Eylemi'nin \% 60'ın üzerinde oranlarla hem eril hem de dişil sıfatlarla tanımlanmış olması; eril ve dişil özelliklerden haksızlığa karşı tavır alan, kendine güvenen, riski göze almaktan çekinmeyen, idealist, kendi ihtiyaçlarını savunan, haksızlığa karşı, insani değerlere duyarlı, sadık, sorumlu, hassas, sevecen, fedakar gibi olumlu olanlarıyla tanımlanmış olması, bizi bu eylemin hem eril hem de dişilliği ifade eden androjen yapıda olduğu tespitine götürmektedir.

Bem (1985), bir bireyin hem erkeksi ve hem de kadınsı özelliklere sahip olup, farklı durumlar karşısında gösterdiği tepkileri bu eğilime göre farklı derecelerde ortaya koyabildiğini söylemektedir. İşte androjenlik kavramı, belli bir kültürde geleneksel cinsiyet rollerinin dışına çıkan ve tipik olarak erkeksi olduğu düşünülen olumlu özelliklerle, tipik olarak kadınsı olduğu kabul edilen olumlu özellikleri birleştiren bir kişilik tipidir. Bu kavram, geleneksel kadınsılık ve erkeksilik kavramlarına ve ruh sağlığıyla ilgili olarak ortaya konan cinsiyet yanlısı ölçütlere karşı geliştirilmiş liberal ve insanca bir seçenek sunduğu için oldukça desteklenmiştir (Bem, 1985, akt.: Güldü ve Kart, 2009)

Rubinstein tarafından yapılan bir çalışmada, androjen cinsiyet rolü kimliğine sahip olan kadınların ve erkeklerin Amerikan ordusunun Kamboçya ve Orta Doğu'ya karışmasına, cinsiyeti tipleşmiş olan kadın ve erkeklerden daha az destek olmak eğiliminde oldukları; Ayrıca androjen erkeklerin maskülen erkeklere göre, siyasal çatışmanın çözümlenmesinde askeri güç kullanılmasına daha fazla karşı çıkmaktadırlar (Rubinstein,1995, akt.:Güldü ve Kart, 2009).

Anket sonuçları, bu eyleme 15 ile 55 ve üstü yaş arası, arkeologdan esnafa, pazarlamacıdan avukata, doktordan müzisyene, akademisyenden kuaföre, teknisyenden tiyatrocuya her meslekten ve gelir düzeyinden, her siyasi görüşten, farklı inançlardan insanın katıldığını göstermiştir. $\mathrm{Bu}$ kozmopolit yap1, kendi içinde bir karmaşaya dönüşmek yerine, "çapulcu” üst kimliğinde birleşerek beklentilerini, neden orada olduklarını ortak bir dille ve kendilerine özgü yöntemlerle anlatmaya çalışmıştır. Hiçbir siyasi parti ya da grubun altında durmayarak "halk" olarak orada olunduğu daima vurgulamıştır.

Cumhuriyet tarihi incelendiğinde Gezi Eylemi'nin halk ayaklanması niteliklerini taşıyan tek eylem olduğu görülür. Kadını görünür kılan da budur. Gezi olaylarına kadar genellikle örgütlü kadınlar, toplumsal ve siyasal hakları için meydanlarda iken bu kez örgütlü-örgütsüz hep beraber meydanlardaydılar; yani eril kültürün onları dışında tutmaya çalıştığı kamusal alandaydılar. Sayıca fazlaydılar ve farklıydılar. Meydanlarda olmayı bilmiyorlardı, acemiydiler ama eril kültürün, kadının pek de anlamadığını söylediği siyasetin içindeydiler. Kaygılarını, beklentilerini, istediklerini, istemediklerini duyurmaya, varlıklarını göstermeye çalışıyorlardı. Duyuldular ve görünür olmayı başardılar. Çünkü kadınlar erkeklerle omuz omuzaydılar, bir eril gibi girişkendiler, gözü pektiler, idealist ve kendine güvenen bir tavır içinde haksızlık olarak niteledikleri durumlara karşı tavır alıyorlardı. Diğer taraftan erkekler de çiçek savurarak, namaz kılan arkadaşlarına şemsiye tutarak, yemek yaparak, temizlik yaparak; duygusal, fedakar, hassas, cana yakın, sevecen bir tutum içinde bir dişil gibi hayatı her alanda kadınlarla paylaşıyorlardı. Çünkü ne erildiler ne de dişil; hem erildiler hem de dişil. Gezi Eylemi'ndeki kadın da erkek de, hem eril hem de dişil kültürün yaşamsal değerleri önde 
tutan özelliklerini sergiliyorlardı; dolayısıyla androjendiler ve Gezi Eylemleri de eylemcilerinden dolayı androjen bir yapı sergiledi.

$\mathrm{Bu}$ çalışma sonunda araştırmacılar beklediklerinden çok daha fazla cevaba ulaşmışlar, bu cevaplar ise onları çok daha fazla soru sormak zorunda bırakmıştır. Eril kültürün şekillendirdiği dünya, "dişil”i eril olmaya mecbur bırakmış; eril de bu değişimden etkilemiş ve az da olsa dişil yönde evrilmiştir. Görünen odur ki eril kültürün çatışmacı, hırslı, otoriter, kuralcı, katı, baskın tavrı ne doğaya, ne insanlara, ne de dünya barışına bir katkı sağlamıştır. Bu durumda, toplumlar eril kültürün tahakkümünden kurtulup androjene dönüşebilmenin mücadelesini mi vermelidirler, yoksa çare dişil kültürde midir?

$\mathrm{Bu}$ çalışma kapsamında Gezi Eylemi’nin yapısı, ortaya çıkış nedenleri ve sonuçlarının erilliği ve dişilliğinin sosyolojik, kültürel ve psikolojik açılardan çok boyutlu olarak araştırılarak androjen ve dişil yapının çağımız için öneminin ortaya konulması konusunda istek uyandırması umut edilmektedir. Bu çalışmanın ileride yapılacak çalışmalara, konuyu geliştirecek olanlara yol göstermesi umulmaktadır.

\section{Kaynakça}

Çarıkçı, İ, H. \& Atilla, G. (2009). Erillik/Dişillik boyutunun empatik beceri ile ilişkisi. Alanya Isşletme Fakültesi Dergisi, s.52-63.

Çatalcalı, A. (2002). Medya dilinin cinsiyeti: köşe yazılarında eril ve dişil sunumlarla toplumsal cinsiyetin konumlandirılmasi.

Dökmen, Y, Z. (1999). Bem cinsiyet rolü envanteri kadınsılık ve erkeksilik ölçekleri türkçe formunun psikometrik özellikleri. Kriz Dergisi, 7 (1), s.27-40.

Dökmen, Z. (1991). Bem Cinsiyet Rolü Envanterinin geçerlik ve güvenirlik çalışması. Dil ve Tarih-Coğrafya Fakültesi Dergisi, 35 (1):81-89.

Güldü, Ö.\&Kart, E. M. (2009). Toplumsal Cinsiyet Rolleri ve Siyasal Tutumlar: Sosyal Psikolojik Bir Değerlenirme. Ankara Üniversitesi SBF Dergisi, s.64-3

Günay, G. \& Bener, Ö. (2011). Kadınların Toplumsal Cinsiyet Rolleri Çerçevesinde Aile içi Yaşam Algılama Biçimleri. TSA. Y1l:15, s.3.

Kongar, E. \& Küçükkaya, A. (2013). Türkiye'yi sarsan otuz gün (10. Bs.). Gezi Direnişi. İstanbul: Cumhuriyet Kitapları.

Metin, A. Kimliğin Toplumsal İnşası ve Geleneksel Kadın Kimliğinin Aktarımı. Çankııı Karatekin Üniversitesi Sosyal Bilimler Enstitüsü Dergisi 2(1), s.74-92.

Sancar, N. (2013). Sicak Haziran. Sonraki Direnişe Mektup (1. bs.). İstanbul: Evrensel Kültür Kitaplığı.

Sankır, H. (2010). Eril Tahakküm ve Üstün Erillik Olgusunun Plastik Sanatlar Alanında Toplumsal Cinsiyet Rollerinin Oluşumuna Etkileri Üzerine Sosyolojik Bir Değerlendirme.

Temel, A. \& Yakın, M. \& Misci, S.(2006). Örgütsel Cinsiyetlerin Örgütsel Davranışa Yansıması. Yönetim ve Ekonomi. 13/1, s.27-38. 


\section{EK1: Çalıșmada Kullanılan Anket Formu}

Bu anket gezi eylemlerine katılmış ya da katılmamış olan herkesin doldurabileceği şekilde hazırlanmıştır. Lütfen anketin tüm bölümlerini doldurunuz. Bu çalışma bilimsel bir çalışmadır. Sizin yapacağınız bu tespitler, elde edilecek ve yorumlanacak sonuçlar açısından büyük önem taşımaktadır.

Katkılarınız için şimdiden teşekkür ederiz.

\section{Geliştirenler:}

Fatma Ebru Özen (e-posta:ebrukaan@gmail.com)

Yasemin Sağlam (eposta:yasemingunduz75@hotmail.com)

\section{KATILIMCI PROFILI}

\section{I.BÖLÜM}

1. Cinsiyetiniz: ( ) Erkek ( ) Kadın

2. Doğum yılınız :

3. Medeni durumunuz: ( ) Evli ( ) Bekar

4. Mesleğiniz:

5. Yaşadığınız şehir:

6. Öğrenim durumunuz
( ) İlkokul
( ) Önlisans
( ) Doktora
( ) Ortaokul
( ) Lisans
( ) Hiçbiri
( ) Lise
( ) Lisansüstü

7. Gezi protestolarına katıldınız mı: ( ) Evet ( ) Hayır

8. Katıldıysanız kaçıncı gün katıldınız:

\section{BÖL ÜM}

Anketin bu kısmında Gezi Eylemleri'ne katılanların neden orada oldukları irdelenmektedir. Eyleme katılanların, eyleme neden katıldıklarına ilişkin aşağıda sıralanan ifadeleri, kendi düşünceniz doğrultusunda derecelendiriniz.

1. Toplumun ihtiyaçlarına ve insani değerlere karşı duyarlı oldukları/ olduğumuz için.
( ) Tamamen kat1lyorum
( ) Kat1liyorum
( ) Fikrim yok
( ) Çok az katılıyorum
( )Hiç katılmıyorum

2. Tehlikeleri göze alabilecek kadar fedakar oldukları/olduğumuz için.
( ) Tamamen katıliyorum
( ) Kat1liyorum
( ) Fikrim yok
( ) Çok az katılıyorum
( )Hiç katılmıyorum

3. Doğaya, çevreye karşı hassas insanlar oldukları/ olduğumuz için.
( ) Tamamen kat1liyorum
( ) Kat1liyorum
( ) Fikrim yok
( ) Çok az katıliyorum
( )Hiç katılmıyorum

4. Eylemde bulunanların ihtiyaç duydukları manevi desteği sağlayacak kadar duygusal oldukları/olduğum için.
( ) Tamamen kat1liyorum
( ) Katıliyorum
( ) Fikrim yok
( ) Çok az katılıyorum
( )Hiç katılmıyorum

5. Tüm canlı varlıklara karşı sevecen bir tutum içinde oldukları/ olduğumuz için.
( ) Tamamen kat1liyorum
( ) Katıliyorum
( ) Fikrim yok
( ) Çok az katılıyorum
( )Hiç katılmıyorum

6. Gezi eylemine destek vermek konusunda sorumluluk duydukları/duyduğum için.
( ) Tamamen kat1liyorum
( ) Kat1liyorum
( ) Fikrim yok
( ) Çok az katılıyorum
( )Hiç katılmıyorum

7. Merhametli oldukları/olduğum için.
( ) Tamamen katiliyorum
( ) Katıliyorum
( ) Fikrim yok
( ) Çok az katılıyorum
( )Hiç katılmıyorum

8. Uzlaşmacı oldukları/olduğum için.
( ) Tamamen katıliyorum
( ) Katıliyorum
( ) Fikrim yok
( ) Çok az katılıyorum
( )Hiç katılmıyorum

9. İnandıkları değerlere sadık oldukları/ inandığım değerlere sadık olduğum için.
( ) Tamamen katıliyorum
( ) Kat1lyorum
( ) Fikrim yok
( ) Çok az katılıyorum
( )Hiç katılmıyorum

10. Oradaki insanlara merhamet edilmesi gerektiği için.
( ) Tamamen katıliyorum
( ) Katıliyorum
( ) Fikrim yok
( ) Çok az katılıyorum
( )Hiç katılmıyorum 
11. Yardıma muhtaç oldukları için.
( ) Tamamen kat1liyorum
( ) Katıliyorum
( ) Fikrim yok
( ) Çok az katılıyorum
( )Hiç katılmıyorum

12. Eylemler etkileyici, eylemciler güçlü olduğu için.
( ) Tamamen katıliyorum
( ) Katıliyorum
( ) Fikrim yok
( ) Çok az katılıyorumv( )Hiç katılmıyorum

13. Haksızlığa karşı tavır aldıkları/ aldığım için.
( ) Tamamen katiliyorum
( ) Katıliyorum
( ) Fikrim yok
( ) Çok az katılıyorum
( )Hiç katılmıyorum
14. İdealist oldukları/olduğum için.
( ) Tamamen katıliyorum
( ) Katiliyorum
( ) Fikrim yok
( ) Çok az katılıyorum
( )Hiç katılmıyorum

15. Kendi ihtiyaçlarını savundukları/ ihtiyaçlarımı savunduğum için.
( ) Tamamen katıliyorum
( ) Katıliyorum
( ) Fikrim yok
( ) Çok az katılıyorum
( )Hiç katılmıyorum

16. Kendilerine güvendikleri/kendime güvendiğim için.
( ) Tamamen kat1liyorum
( ) Kat1liyorum
( ) Fikrim yok
( ) Çok az katılıyorum
( )Hiç katılmıyorum

17. Orada olanlar mantıklı insanlar oldukları/ mantıklı olduğum için.
( ) Tamamen katıliyorum
( ) Kat1liyorum
( ) Fikrim yok
( ) Çok az katılıyorum
( )Hiç katılmıyorum

18. Riski göze almaktan çekinmedikleri/çekinmediğim için.
( ) Tamamen katıliyorum
( ) Katıliyorum
( ) Fikrim yok
( ) Çok az katılıyorum
( )Hiç katılmıyorum

19. Çatışmacı oldukları/olduğum için.
( ) Tamamen kat1liyorum
( ) Kat1liyorum
( ) Fikrim yok
( ) Çok az katılıyorum
( )Hiç katılmıyorum

20. Haksızlığa karşı durmak konusunda lider bir ruha sahip oldukları/olduğum için.
( ) Tamamen katıliyorum
( ) Katıliyorum
( ) Fikrim yok
( ) Çok az katılıyorum
( )Hiç katılmıyorum

21. Cömert oldukları/olduğum için.
( ) Tamamen katıliyorum
( ) Kat1liyorum
( ) Fikrim yok
( ) Çok az katılıyorum
( )Hiç katılmıyorum

22. Kuralcı ve katı oldukları olduğum için.
( ) Tamamen katıliyorum
( ) Kat1liyorum
( ) Fikrim yok
( ) Çok az katılıyorum
( )Hiç katılmıyorum

\section{III.BÖLÜM}

Hükümetin Gezi Eylemleri sırasında medya aracılığıyla doğrudan ve de polis aracılığıyla dolaylı olarak sergilediği tavrını değerlendirmek için, aşağıdaki ifadeleri okuyarak derecelendiriniz.

1. Fedakar bir tutum içindeydiler.
( ) Tamamen katıliyorum
( ) Kat1liyorum
( ) Fikrim yok
( ) Çok az katılıyorum
( )Hiç katılmıyorum

2. İnsanlara yaklaşımı merhametliydi.

( ) Tamamen kat1liyorum

( ) Katıliyorum

( ) Fikrim yok

( ) Çok az katılıyorum

( )Hiç katılmıyorum

3. Eylemcilere karşı tutumları pasifti.

( ) Tamamen katıliyorum

( ) Katıliyorum

( ) Fikrim yok

( ) Çok az katılıyorum

( )Hiç katılmıyorum

4. Kaba dil kullanmadılar.

( ) Tamamen katıliyorum

( ) Kat1lyorum

( ) Fikrim yok

( ) Çok az katılıyorum

( )Hiç katılmıyorum

5. Olaylara duygusal yaklaştılar.

( ) Tamamen katılıyorum ( ) Katıliyorum

6. Eylemcilere karşı anlayış̧ıydılar.

( ) Tamamen katıliyorum ( ) Katıliyorum

7. Uzlaşmacı bir tutum içerisindeydiler.

( ) Tamamen kat1liyorum ( ) Katıliyorum

8. Kibar davranışlar sergilediler.

( ) Tamamen katıliyorum ( ) Katıliyorum
( ) Fikrim yok

( ) Çok az katılıyorum

( ) Fikrim yok

( ) Çok az katılıyorum

( ) Fikrim yok

( ) Çok az katılıyorum

( ) Fikrim yok

( ) Çok az katılıyorum

( )Hiç katılmıyorum

( )Hiç katılmıyorum

( )Hiç katılmıyorum

( )Hiç katılmıyorum 
9. Eylemcilere karşı boyun eğen bir tavırları vardı.

( ) Tamamen katılıyorum ( ) Katılıyorum ( ) Fikrim yok ( ) Çok az katılıyorum （ )Hiç katılmıorum

10. Cana yakın bir tutum içindeydiler.

( ) Tamamen katılıyorum ( ) Katılıyorum ( ) Fikrim yok （）Çok az katılıyorum （ )Hiç katılmıyorum

11. Ağırbaşlı ve ciddiydiler.

( ) Tamamen katılıorum ( ) Katılıyorum （）Fikrim yok （）Çok az katılıyorumv ( )Hiç katılmıyorum

12. Davranışları baskın ve tesirliydi.

( ) Tamamen katılıyorum ( ) Katılıyorum
13. Duygularını açığa vurmadılar.

( ) Fikrim yok ( ) Çok az katılıyorum （ )Hiç katılmıyorum

( ) Tamamen katıliyorum ( ) Katıliyorum

( ) Fikrim yok ( ) Çok az katılıyorum （ )Hiç katılmıyorum

14. Etkileyici ve güçlï tavırlar sergilediler.

( ) Tamamen katılıyorum ( ) Katılıyorum （）Fikrim yok （）Çok az katılıyorum （ )Hiç katılmıyorum

15. Otoriter davrandılar.

( ) Tamamen katılıyorum

( ) Katıliyorum

( ) Fikrim yok

( ) Çok az katılıyorum

( )Hiç katılmıyorum

16. Kuralcı ve katıydılar.

( ) Tamamen katıliyorum

( ) Katıliyorum

( ) Fikrim yok

( ) Çok az katılıyorum

( )Hiç katılmıyorum

17. Etkin (aktif)diler.

( ) Tamamen kat1liyorum

( ) Katıliyorum

( ) Fikrim yok

( ) Çok az katılıyorum

( )Hiç katılmıyorum

18. Hakimiyet kurmaya çalıştılar.

( ) Tamamen katılıyorum ( ) Katılıyorum ( ) Fikrim yok （）Çok az katılıyorum （ )Hiç katılmıyorum

19. Çatışmacı bir tavır içindeydiler.

( ) Tamamen katılıyorum ( ) Katılıyorum ( ) Fikrim yok ( ) Çok az katılıyorum ( )Hiç katılmıyorum

20. Tavirları saldırgandı.

( ) Tamamen katılıyorum ( ) Katılıyorum （）Fikrim yok （）Çok az katılıyorumv ( )Hiç katılmıyorum

21. Kendine güvenen bir tavır içindeydiler.

( ) Tamamen katılıyorum （ ) Katılıyorum （）Fikrim yok （）Çok az katılıyorum （ )Hiç katılmıyorum

22. Olaylar karşısında gözüpek bir tutum sergilediler.

( ) Tamamen katılıyorum ( ) Katılıyorum （） Fikrim yok （）Çok az katılıyorum （ )Hiç katılmıyorum 